\title{
THE NAKOVANA ZODIAC: FRAGMENTS OF AN ASTROLOGER'S BOARD FROM AN ILLYRIAN-HELLENISTIC CAVE SANCTUARY
}

\author{
STAŠO FORENBAHER, Institute for Anthropological Research, Zagreb, and \\ ALEXANDER JONES, New York University
}

\section{Introduction}

In year 2000, fragments of engraved ivory objects were found in the course of archaeological excavations at Nakovana Cave in southern Croatia. Post-excavation refitting proved that the fragments belonged to several ivory plaques, each one bearing an engraved zodiacal symbol. Most likely, these plaques were parts of an astrologer's board, a rare find by any measure. They were recovered under closely controlled conditions, from a tight cluster of fine Hellenistic ceramic vessels that were left as offerings in the cave sanctuary.

Nakovana Cave overlooks the Adriatic Sea from just below the crest of a 400m high ridge near the strategically important western tip of Pelješac Peninsula, 100km northwest of Dubrovnik on Croatia's Dalmatian coast (Figure 1). From above the cave entrance, the islands of Vis (Issa), Hvar (Pharos), Korčula (Korkyra Melaina), and Mljet are in plain view, while the mouth of Neretva River (ancient Naron), a major route into the western Balkans interior, lies just twenty miles to the east. Some of the most important Adriatic sea-lanes of Antiquity pass through the channels beneath the cave.

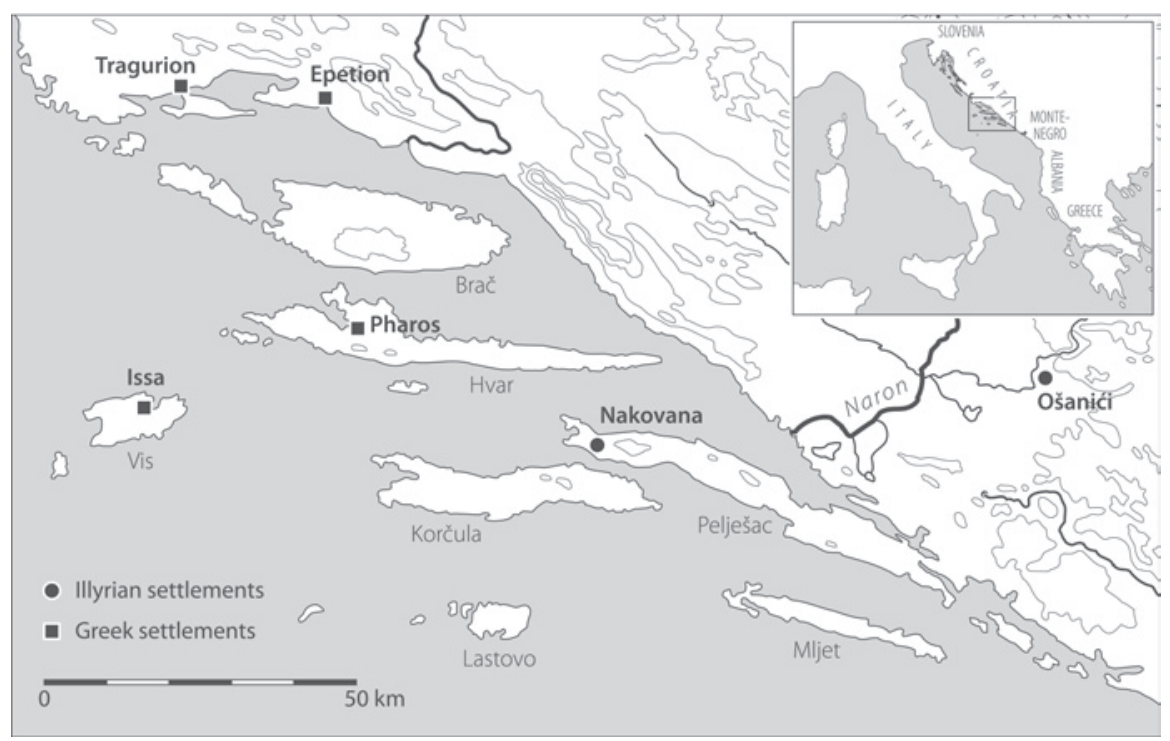

FIG. 1. Middle Dalmatia, showing the location of Nakovana and other sites mentioned in the text. 
Villagers of the neighbouring hamlet of Nakovana call the site simply 'Spila' ('the cave'), hinting at its particular importance, compared to many other caves in the area. Its entrance looks like a horizontal slit cut into the limestone, opening onto a deep rock shelter, about $15 \mathrm{~m}$ wide but only $2 \mathrm{~m}$ high at the front. Its ceiling slopes down to meet a rubble-strewn floor some $15 \mathrm{~m}$ away. The cave seems to end here, but the stone rubble actually chokes a wide, low passageway, which slopes slightly downward into the dark for almost ten metres. Beyond that, the cave opens up, revealing a long, high-ceilinged channel that widens to form two fairly spacious chambers. Total length of the cave is 60 metres (Figure 2).

\section{Circumstances of Discovery}

When the 'Nakovana Project' (directed by Timothy Kaiser and Stašo Forenbaher) began its work in 1999, Nakovana Cave was already well known as the type-site for the eastern Adriatic Early Copper Age. ${ }^{1}$ Initially we focused on a deep sounding (Sector 1) located near the entrance (Figure 2), where cultural deposits about $4 \mathrm{~m}$ thick spanned most of the post-Mesolithic prehistoric sequence. At the time, we were not aware that the cave extended beyond the rockshelter's apparent end. We discovered its dark interior near the end of the field season, after removing some of the stone rubble and crawling through the tight passage.

On our first visit to the hidden channel, an undisturbed, fragile stalagmitic crust covered much of the cave floor. Fragments of many pottery vessels were lying about, most of them Hellenistic finewares, datable to the last four centuries B.C. They were
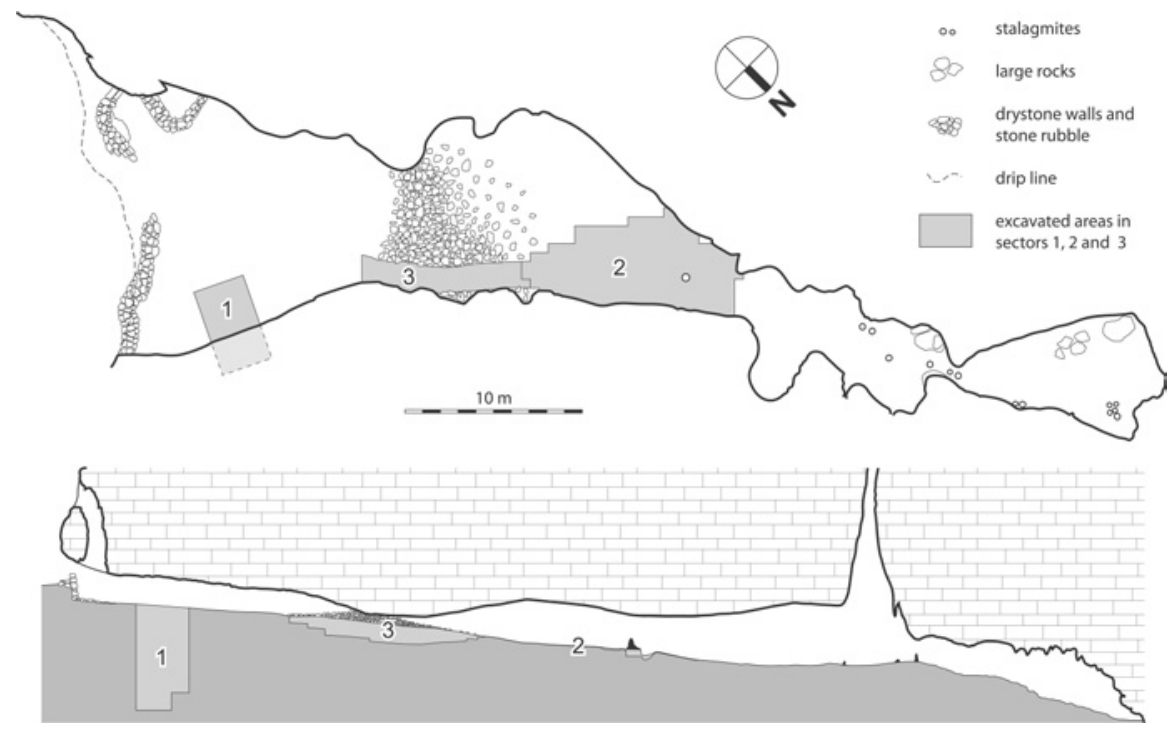

FIG. 2. Plan and section of Nakovana Cave, showing excavated areas. 


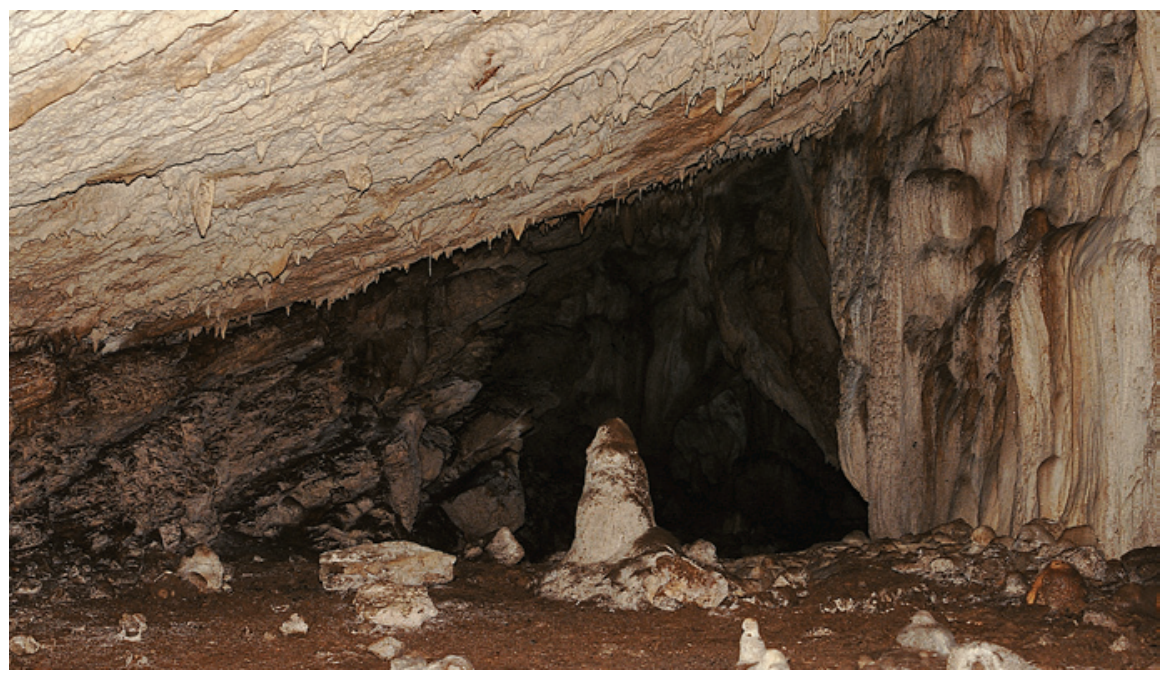

FIG. 3. The interior chamber of Nakovana Cave.

exceptionally well preserved and, judging from their associations, appeared to have been left where they were broken. Clearly, the entrance to the channel was choked a long time ago, sealing off the back of the cave.

Over the course of the next two seasons, we excavated the Hellenistic layer in Sector 2, exposing 47 square metres of its surface (Figure 2) and removing about three tons of cultural deposit. ${ }^{2}$ Overlying earlier prehistoric deposits, this surface layer was rarely more than a few centimetres thick and petered out completely beyond the excavated area. Most of the finds from within this layer were recovered from a small space, barely $2 \mathrm{~m}$ across, located immediately in front of the chamber's dominant feature, a single, large stalagmite (Figure 3).

Extremely high density of unusually well preserved finds, embedded in a matrix of highly plastic wet clay, called for particularly careful recovery methods. Excavation proceeded in half-metre squares, and all excavated sediment was transported to the field laboratory where it was wet-sieved on tables with $3 \mathrm{~mm}$ meshes, aided by a high-pressure water gun.

All of the engraved ivory fragments were recovered during wet sieving. Many of them, including the largest and best-preserved fragments, came from the area immediately in front of the prominent stalagmite, which also contained most of the Hellenistic fineware vessels (Figure 4). Other, smaller fragments were scattered within two metres distance from the stalagmite.

\section{Description and Reconstruction of the Find}

Thirty fragments of worked ivory were recovered, coming from at least seven plaques of nearly identical size and shape. After refitting, four plaques were fully or partially 


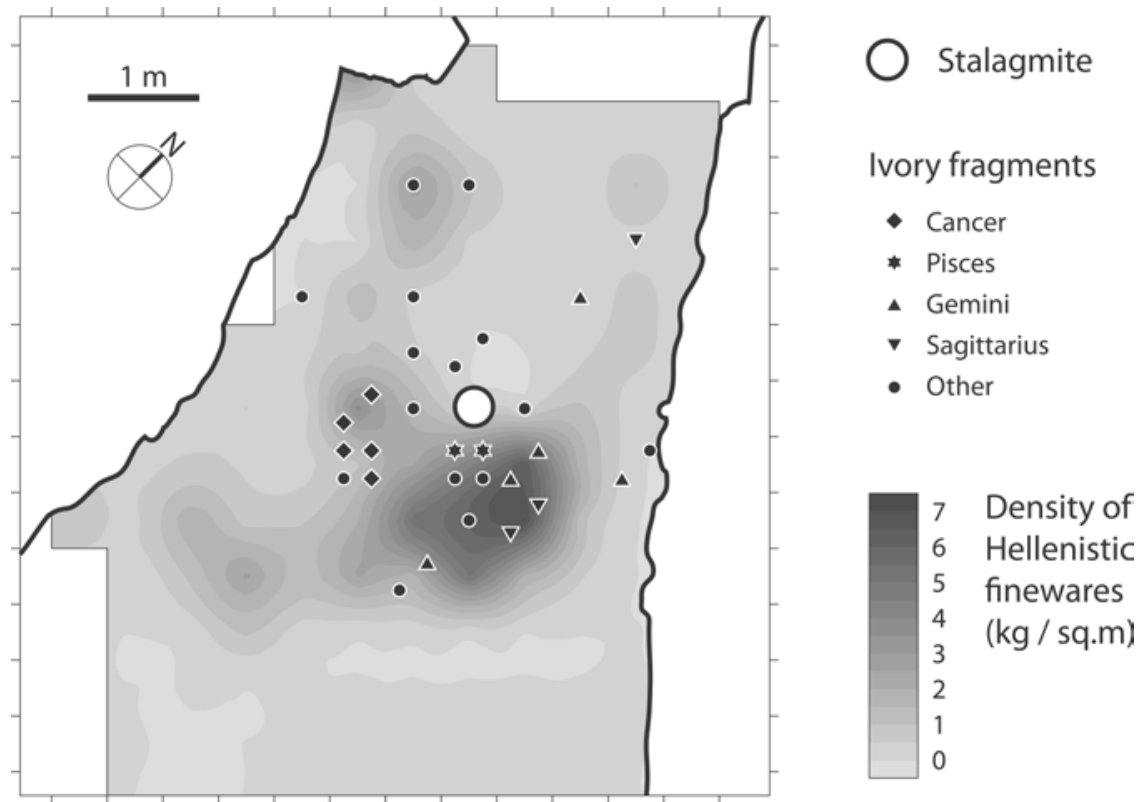

FIG. 4. Distribution of Hellenistic finewares and ivory fragments around the stalagmite.

reconstructed, while a number of small fragments must have come from at least three more plaques, judging by their sizes and shapes (Figures 5 and 6).

Each plaque was shaped as an arc segment spanning approximately 28 degrees, $30 \mathrm{~mm}$ wide, about $55 \mathrm{~mm}$ long on the outside, about $40 \mathrm{~mm}$ long on the inside, and usually two to three millimetres thick. They would have been mounted on a flat (wooden?) surface to which they would have been attached by an adhesive. Parallel incised lines that crisscross the plaques' reverse side (Figure 7) may have been intended to provide a better grip for the adhesive.

Four of the plaques bear recognizable motifs on the obverse side, executed by fine line engraving: a crab, two fishes, a couple of human figures, and a body and hind legs of a large running animal.

Plaque 1 (Figure 6:1) bears a realistic depiction of a crab. It is virtually complete, refitted from five fragments found close to each other, about $1 \mathrm{~m}$ to the southwest of the stalagmite. We interpret it as zodiacal symbol of Cancer.

Plaque 2 (Figure 6:2) bears a realistic depiction of two human figures standing next to each other, the left one positioned slightly higher then the right one. The upper right corner and a middle lower part of the plaque are missing. It was refitted from five fragments that were scattered within $1.5 \mathrm{~m}$ to the south, east and north of the stalagmite. Both figures seem to be males. Their naked bodies are shown with considerable anatomical precision, following classical artistic tradition. The one on 
the left is missing most of his right leg and upper part of left leg, as well as left arm and shoulder. His right arm is extended, and his head is turned towards the other figure. The one on the right is missing the upper part of his torso, both arms and head. Behind his legs and reaching down to his ankles is the lower part of a robe. We interpret it as zodiacal symbol of Gemini.

Plaque 3 (Figure 6:3) bears a realistic depiction of two fishes. The upper right corner and the right end of the plaque are missing. It was refitted from two fragments, both found right in front of the stalagmite. Only the tail part of one of the fishes has been preserved, while the other fish is complete. Curving lines issuing from both of their tails converge to a point at the left margin of the plaque. We interpret it as zodiacal symbol of Pisces.

Plaque 4 (Figure 6:4) bears a realistic depiction of a running or jumping animal. About half of the plaque is present, refitted from three fragments that were scattered within $2 \mathrm{~m}$ to the east and north of the stalagmite. Preserved elements of the design show the middle part of the body, buttocks, parts of both hind legs with clearly marked ankles, and the tail composed of several long tresses of hair. Extended legs and flying tail suggest a horse-like animal in rapid motion. We interpret it as zodiacal symbol of (most likely) Sagittarius.

Four more fragments preserve parts of engraved designs. One apparently depicts a (human?) leg (Figure 6:7), another may be showing a leg of an animal (Figure 6:6), while the remaining two, although carefully executed, are too fragmented to be recognizable (Figures 6:5 and 6:8). The remaining fragments have plain obverse side.

Allowing for a narrow $\left(2^{\circ}\right)$ wedge of space between the plaques, twelve of them would have constituted a full circle with an outer diameter of about $21.5 \mathrm{~cm}$ (Figure 8). There can be little doubt that these plaques, each one bearing a zodiacal symbol, represented the Greek zodiac. Most likely, they were a part of an astrologer's board.

\section{Astrologer's Boards}

The astrologer's board was a central item of an astrologer's apparatus. It served for visualizing and interpreting horoscopes, as well as to impress the client. A passage in the Alexander romance, a Greek adventure novel surviving in manuscript of the third century A.D. and cited in full by Evans, ${ }^{3}$ provides a fairly detailed description of such a "princely and costly" object made of ivory, ebony and gold.

That description fits remarkably well the few known examples of astrologer's boards preserved from Antiquity. The short list of these relatively small, portable objects includes the ivory tablets from Grand, ${ }^{4}$ the now lost Daressy tablet ${ }^{5}$ and the Tabula Bianchini ${ }^{6}$ both made of marble, and possibly the Tanis zodiac made of glass and decorated with gold leaf. ${ }^{7}$ Their dimensions vary between $20 \mathrm{~cm}$ and $30 \mathrm{~cm}$, except for Tabula Bianchini which measures $58 \mathrm{~cm}$ across. ${ }^{8}$ All of them have several concentric zones with astrological symbols. The twelve signs of the zodiac are always present, usually encircling the Sun and the Moon at the centre. Other zones may contain decans, figures of the dodecaoros, terms, a second zodiac, and other 

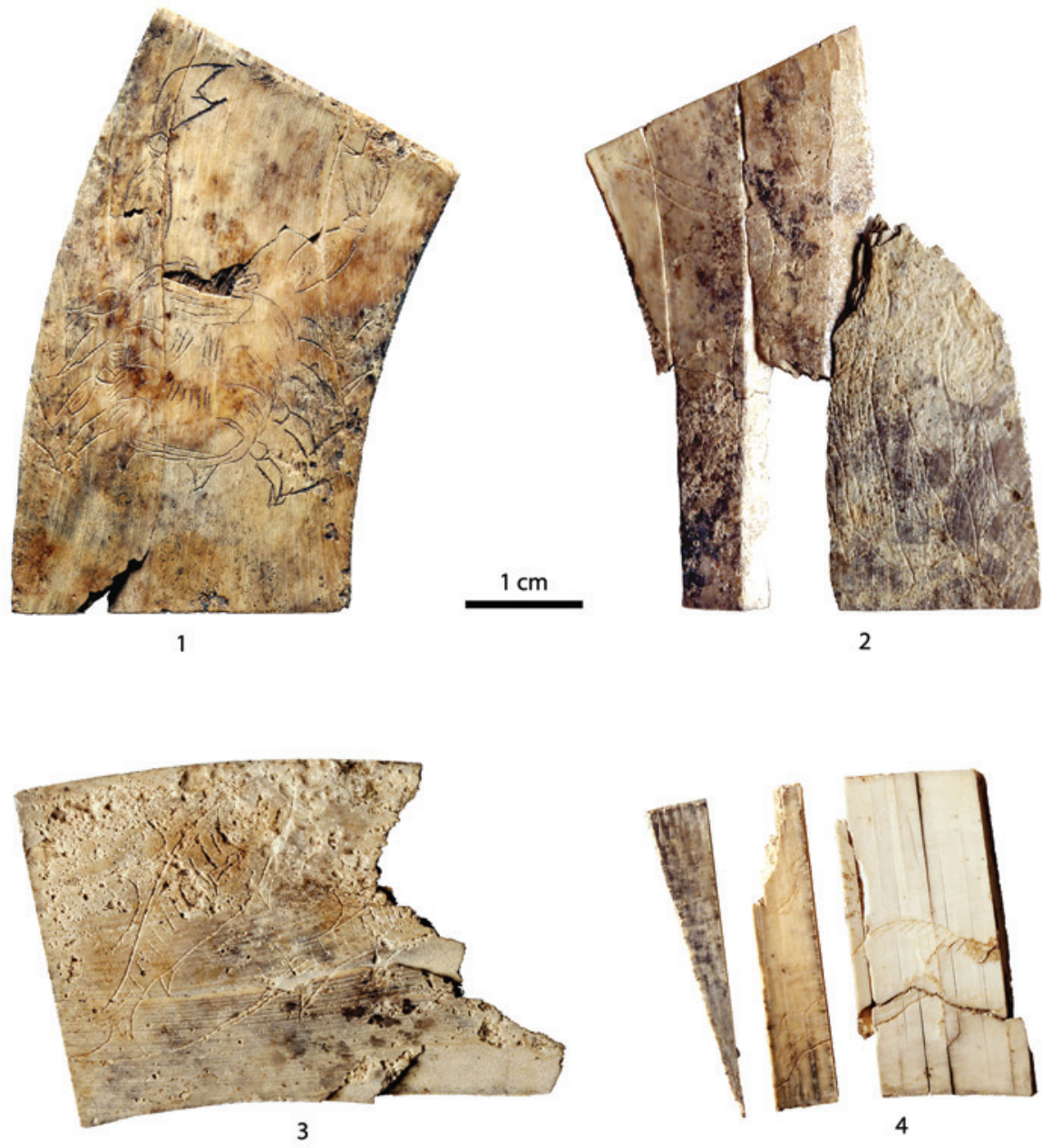

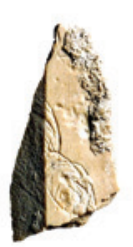

5

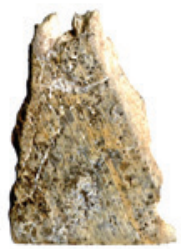

6

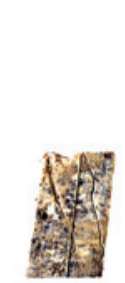

7

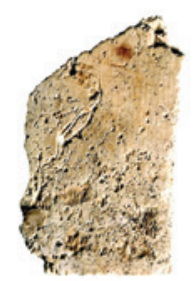

8

FIG. 5. Obverse side of the four refitted ivory plaques and other engraved fragments. 


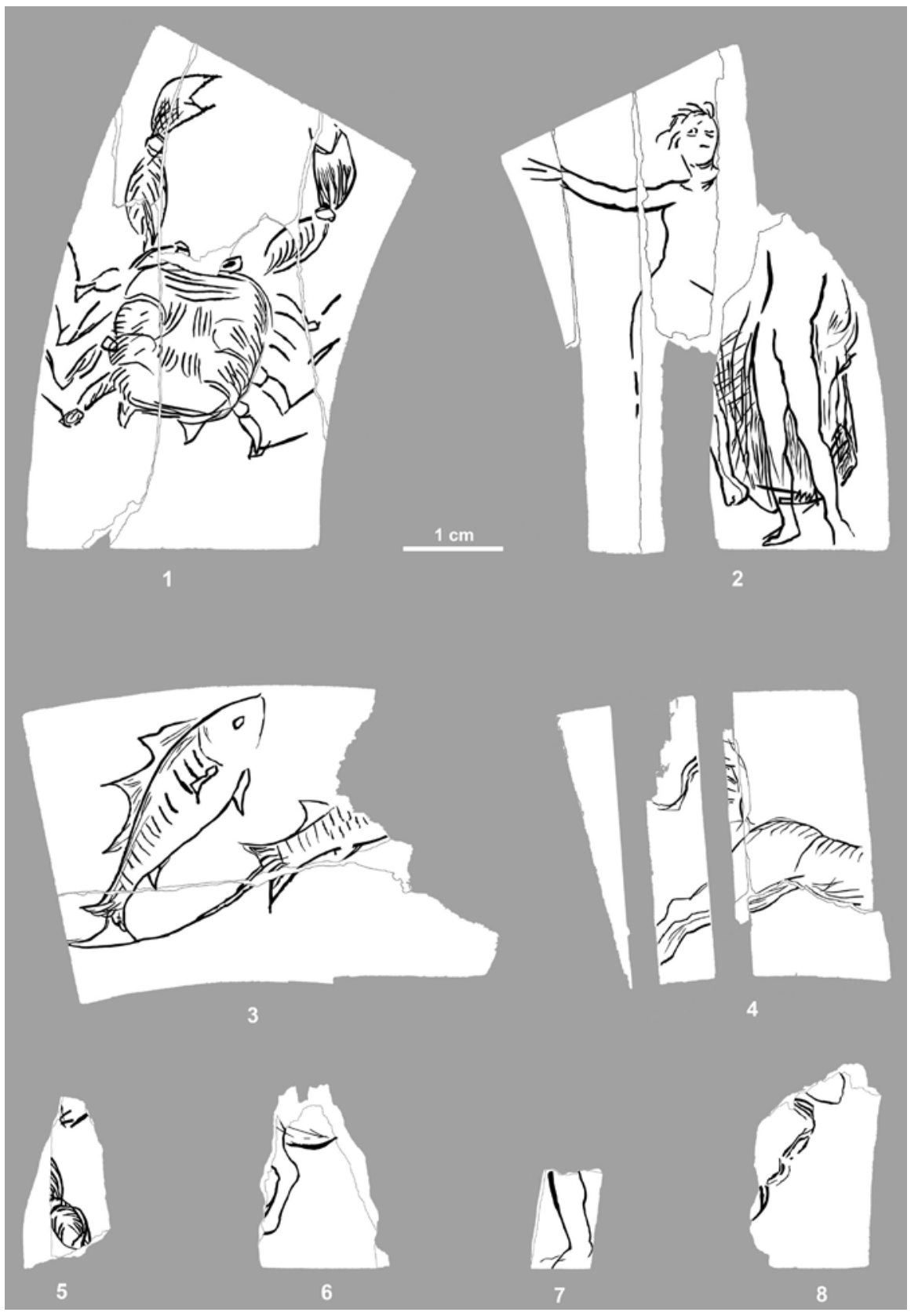

FIG. 6. Drawings of the four refitted ivory plaques and other engraved fragments. 
symbols. ${ }^{9}$ In order to make horoscopic predictions, the astrologer would have placed worked stone markers for the planets at their calculated positions on the board, and interpreted their relationship.

All of these examples are attributed to Roman Imperial times. The tablets from Grand were made in Egypt, probably in the first or second century A.D. ${ }^{10}$ They were thrown into a well near the sanctuary of Apollo Grannus, in what is today eastern France, around A.D. 170. ${ }^{11}$ Dating of the other tablets is based on their iconography. The Daressy tablet and the Tanis zodiac are attributed to the early Roman Imperial period, and the Tabula Bianchini to the second or third century A.D. ${ }^{12}$

The Nakovana zodiac is closely comparable in size to other known examples of astrologer's boards. Like tablets from Grand and the board described in Alexander romance, it is made of ivory, but unlike Grand it is a composite object, assembled from multiple ivory plaques. Furthermore, it differs from Grand stylistically: rather than having Egyptian iconographic affinities, it clearly follows a classical GraecoRoman artistic tradition. The most striking thing about it, however, is its surprisingly early date.

\section{Dating and Origin of the Nakovana Zodiac}

The archaeological context provides a solid base for dating. All fragments of ivory were recovered from the thin Hellenistic layer that covered the surface of the cave's interior chamber. They were found in direct association with thousands of fine Hellenistic ceramic fragments. ${ }^{13}$ The earliest among those ceramic vessels were black glazed skyphoi from the fourth century B.C. and vessels of Alto Adriatico style with painted floral and figural designs from the late fourth or early third century B.C. ${ }^{14}$ Most of the ceramics were local copies of late Gnathia and Campanian wares, produced in Greek colonies in Dalmatia during the third and second centuries B.C. ${ }^{15}$ Among the latest finds are a few Roman vessels, datable to the first century B.C.

While highly suggestive, this evidence does not necessarily imply that the zodiac must be of a Hellenistic date. Surface contexts are notoriously unreliable, since they can easily contain intrusive finds from much later periods. However, it seems that the cave interior was sealed soon after the sanctuary was abandoned. Neither the careful exploration of all interior chambers and channels, nor the extensive excavation in the area around the stalagmite, yielded a single artifact post-dating the first century B.C., or any other evidence of later human visits. Apparently, the entrance passage was intentionally closed at the time of sanctuary's abandonment.

That abandonment can be linked to wider historical events that engulfed the region. The Illyrian lands fell under Roman control after a long and grim series of campaigns, beginning with the First Illyrian War of 229 B.C. Almost two centuries later, Octavianus decided to subdue Illyrians once and for all. His military campaigns lasted from 35 to 27 B.C., encompassing most of the eastern Adriatic and its hinterland. ${ }^{16}$ According to Appianus, Roman army massacred native populations of the islands of Korčula and Mljet during the first year of operations. ${ }^{17}$ It is unlikely 
that the strategically important western end of Pelješac Peninsula, lying directly across the narrow straits from Korčula, would have been spared. Our survey of that microregion found virtually no evidence of occupation during the Early Imperial or later Roman periods, suggesting that western Pelješac, including the area around Nakovana Cave, was depopulated during those times.

Taken together, this evidence provides a terminus ante quem of 35 в.c. for the deposition of the engraved ivory plaques in the cave sanctuary. Such an early date is further supported by direct radiocarbon dating. A cumulative sample of seven tiny, undecorated ivory fragments yielded a single accelerator mass spectrometry date of $2217 \pm 21$ B.P. (laboratory identification code UBA-14650). Its calibrated two standard deviations age range is 375-204 B.C., with an asymmetric probability distribution that is skewed towards the third century B.c. This dates the death of the animal whose tusk was used for the engraved plaques.

Greek horoscopic astrology was apparently invented in late Ptolemaic Egypt sometime in the second or early first century B.C. ${ }^{18}$ This means that, most likely, the Nakovana zodiac could not have been produced before the second century B.C., and probably not much before year 100 B.C., implying that the ivory was more than a century old when it was engraved. It also suggests a relatively brief life-span for this object, likely covering the first half of the first century B.C.

Nakovana zodiac is not a local product. In Dalmatia, ivory (probably, elephant tusk) was an exotic material that must have come from afar, most likely from Africa. Iconography, style and technical competence suggest that the plaques were engraved in a workshop at some late Hellenistic cosmopolitan centre, by someone well acquainted with the latest developments in astrology. As argued above, they must have been made very soon after the invention of Greek horoscopic astrology. All of this would make Egypt the most likely candidate for their point of origin.

\section{The Regional Context: Dalmatia in the Last Centuries B.C.}

At the beginning of the first century B.C., Dalmatia was at the verge of being fully incorporated into the Greco-Roman Mediterranean civilization. ${ }^{19}$ This process began in the sixth century B.C. and accelerated around year 400 B.C. when Greeks established successful and long-surviving settlements at Pharos on the island of $\mathrm{Hvar}^{20}$ and Issa on the island of Vis. ${ }^{21}$ Greek polities, however, controlled only small footholds on a few of the Dalmatian islands and maintained an even smaller presence on the mainland. While ever-increasing numbers of Greek and Roman vessels were plying Dalmatian waters, the overwhelming part of the land was still controlled by the autochthonous Illyrians.

Relations between the indigenous populations, the Greek colonists, and the expanding Roman dominion shifted with daily politics from expedient alliances to fullblown armed conflicts. This meant that there was much opportunity for interaction, either peaceful or otherwise. Through commercial or prestige exchange, or through piracy and raiding, substantial quantities of exotic goods ended up in the hands of 


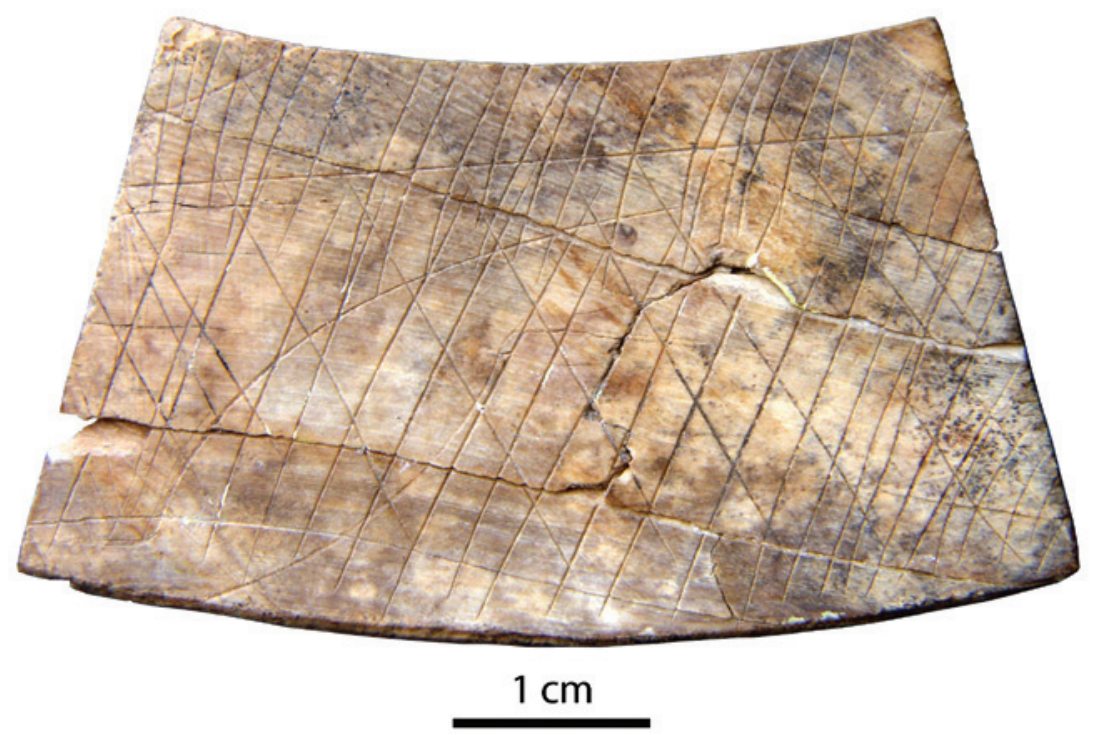

FIG. 7. Reverse side of Plaque 1.

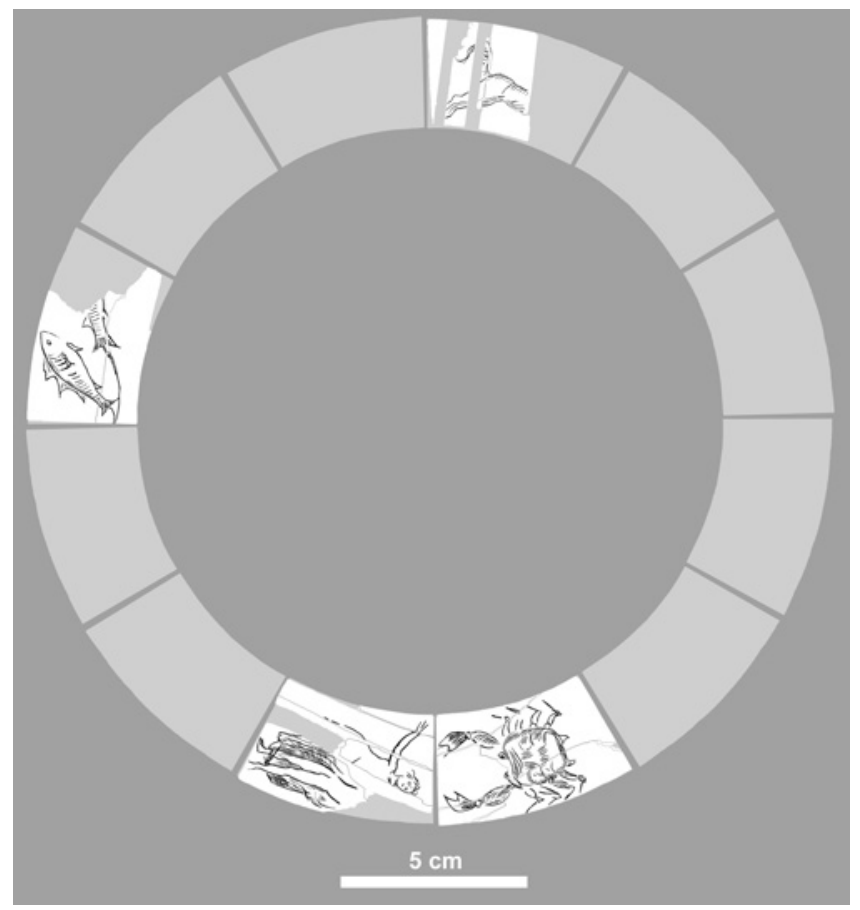

FIG. 8. Reconstructed zodiac from Nakovana Cave. 
local Illyrian potentates. In certain parts of the eastern Adriatic littoral (especially, the middle Dalmatian islands and the adjacent coast, as well as the lower Neretva valley), Late Hellenistic ceramics are often found on Illyrian hillforts as well as in cave sanctuaries, while many otherwise traditional Illyrian cairn burials contain fine Hellenistic ceramics, bronze vessels and weapons. A major Illyrian stronghold of Ošanići yielded spectacular Hellenistic ceramic and bronze imports, and probably minted its own coins. ${ }^{22}$

Clearly, some of the Illyrian élites eagerly accepted elements of Hellenistic material culture and partially emulated the behaviour of their richer, more powerful, technologically more advanced and artistically more refined role models. As the first millennium B.C. was drawing to its close, mobility of people between Greek towns, Roman-controlled territories, and Illyrian strongholds increased, and cultural differences between colonists and locals were becoming ever more blurred.

The local Illyrians who controlled the western end of Pelješac Peninsula were particularly well positioned to take advantage of the shipping passing through busy sea-lanes directly underneath their stronghold. The hillfort of Grad in the middle of Nakovana Plateau had easy access to both coasts of the narrow peninsula, and yet was protected and hidden from view by the steep, rocky coasts. Grad was intensively occupied during the last few centuries B.C. ${ }^{23}$ Overlooking it from just a kilometre away is the Nakovana Cave. Forenbaher and Kaiser ${ }^{24}$ argue that a substantial part of foreign goods, acquired through trading or raiding by the masters of Grad, ended up as offerings at the cave sanctuary.

\section{The Local Context: An Astrologer's Board in a Cave Sanctuary}

How can one explain the presence of an astrologer's board in a cave sanctuary, hidden in the hills at the edge of the civilized world, within a territory controlled by a local indigenous community? Maybe it was deposited there together with other imported items as an offering to the transcendental power worshiped in the cave. Astrology was becoming familiar in Rome from about the middle of the first century B.C., so paraphernalia connected with it would likely have been imported into Italy around this time. The "princely and costly" board may have been plundered from a passing ship by a local pirate who knew nothing about astrology or horoscopes, but who recognized it as a luxury item worthy of gods.

On the other hand, we may be giving too little credit to the Illyrians, picturing them as uncivilized brutes (which is what the classical historians, who were clearly biased against them, often had in mind). By the first century в.C., the indigenous and the colonizing communities in Dalmatia were interacting in multiple ways and on a daily basis, and the distant Mediterranean shores were interconnected as never before. Novelties emanating from the great Hellenistic centres would not have remained locked behind the Greek colonies' town gates.

One can imagine astrologers visiting the Greek colonies in Dalmatia, or maybe even residing there. It is not beyond imagination that they would have offered their 
services to the ever more Hellenized Illyrian élites, eager to participate in the most recent fads. Could it be that an astrologer actually practised his trade in the Nakovana cave sanctuary? After all, astrologers often worked in or near temples, ${ }^{25}$ and the best example of astrologer's boards ever found (and the only one with safe provenience information, aside from the Nakovana Zodiac) comes from a temple complex. ${ }^{26}$

While Evans ${ }^{27}$ provides convincing evidence for placing astrology in the temples of Sarapis, he is quick to add that other gods also smiled upon that craft. At the Nakovana cave sanctuary, real or symbolic feasts were held and offerings were made to a transcendental power whose identity eludes us. Maybe it was an obscure local Illyrian god, or some Graeco-Illyrian syncretic deity. Forenbaher and Kaiser ${ }^{28}$ offered some speculation elsewhere, based on the evidence for copious alcoholic consumption in association with a phallic stalagmite that represented the ritual focus. The Classical pantheon abounds with divine candidates for the protector of the sanctuary that would satisfy these general requirements. Unfortunately, most of what we know about Illyrian beliefs ${ }^{29}$ has been gleaned from archaeological monuments dated to Roman Imperial times, while the specifics of the original Illyrian religion remain largely unreachable and unknown.

An astrological consultation must have been a psychologically powerful experience. Evans ${ }^{30}$ offers a description that is imaginary, but well founded in known facts, of an astrologer practising his trade in a dark chamber of the temple, in a small circle of light provided by a flickering lamp. One can hardly imagine a better stage for such a performance than the interior of Nakovana Cave.

About two-thirds of the Nakovana zodiac are missing. Since the other known examples of astrologer's boards consisted of several concentric zones (the zodiac being but one among them), perhaps only a small part of the complete object has survived. Maybe the board was already damaged and incomplete when it was brought to the cave. Alternatively, if it was complete when left as an offering, someone may have intentionally removed ('stolen') most of its parts during subsequent visits and ritual performances. In either case, it would have been useless to an astrologer.

On the other hand, if the complete board was left lying on the cave floor, changes in humidity and exposure to aggressive agents such as bat dung would have caused material decay. Chemical weathering is visible on the surface of many fragments, and plaques crumble along parallel fracturing lines that break the structure of ivory. If the composite object began falling apart while the shrine was still in use, its parts may have been unintentionally trampled and broken up into tiny unrecognizable fragments, or even removed while sticking to the soles of shoes. After the interior part of the cave became inaccessible to people, destruction continued by other regular visitors such as dormice, snakes and bats.

Finally, like the tablets from Grand, Nakovana zodiac may have been deliberately shattered and some of its parts thrown out of the cave. 


\section{Acknowledgements}

This research has been supported in part by the Ministry of Science, Education and Sports of the Republic of Croatia (project \#196-1962766-2740). Excavations at Nakovana Cave were made possible by a generous gift from Audry and David Mirvish through the Royal Ontario Museum Foundation.

\section{REFERENCES}

1. N. Petrić, "Prethistorijske kulture Pelješca", Pelješki zbornik, i (1976), 295-313; S. Forenbaher, “"Nakovana culture': State of research”, Opuscula archaeologica, xxiii-xxiv (2000), 373-85.

2. S. Forenbaher and T. Kaiser, "Nakovana cave: An Illyrian ritual site", Antiquity, lxxv (2001), 677-8.

3. J. Evans, "The astrologer's apparatus: A picture of professional practice in Greco-Roman Egypt", Journal for the history of astronomy, $\mathrm{xxxv}$ (2004), 1-44, p. 4.

4. J.-H. Abry (ed.), Les tablettes astrologiques de Grand (Vosges) et l'astrologie en Gaule romaine (Lyon, 1993); H. G. Gundel, "Zodiakos: Der Tierkreis in der antiken Literatur und Kunst”, Pauly-Wissowa Realencyclopädie der Classischen Altertumswissenschaft, 2nd ser., vol. XA/19 (Munich, 1972), 463-710, p. 647, no. 147,2; and idem, Zodiakos: Tierkreisbilder im Altertum - Kosmische Bezüge und Jenseitsvorstellungen im antiken Alltagsleben (Mainz, 1992), 232-3, no. 82.

5. Gundel, "Zodiakos" (ref. 4), 632, no. 59; and Gundel, Zodiakos (ref. 4), 226-7, no. 59.

6. Gundel, "Zodiakos" (ref. 4), 632-3, no. 60; and Gundel, Zodiakos (ref. 4), 226, no. 63.

7. Gundel, "Zodiakos" (ref. 4), 658, no. 159; and Gundel, Zodiakos (ref. 4), 240, no. 104.

8. W. Fröhner, Notice de la sculpture antique du Musée Impérial du Louvre, i (Paris, 1869), 15.

9. Evans, op. cit. (ref. 3), 5-10.

10. J.-C. Goyon, "L'origine égyptienne des tablettes décanales de Grand (Vosges), I", in Abry (ed.), Les tablettes astrologiques (ref. 4), 63-75; Evans, op. cit. (ref. 3), 22.

11. J.-P. Bertaux, "La découverte des tablettes: Les données archéologiques", in Abry (ed.), Les tablettes astrologiques (ref. 4), 39-47, p. 44.

12. Evans, op. cit. (ref. 3), 8-10.

13. S. Forenbaher and T. Kaiser, Spila Nakovana: An Illyrian sanctuary on the Pelješac Peninsula (Zagreb, 2003), 73-91; and idem, "Spila Nakovana: An Illyrian sanctuary from the Hellenistic Period”, Homage to Milutun Garašanin, ed. by N. Tasić and C. Grozdanov (Beograd, 2006), 571-82, pp. 574-8.

14. B. Kirigin, "Alto-Adriatico vases from Dalmatia", Adriatico tra IV e III sec. A.C., vasi Alto-Adriatici tra Piceno, Spina e Adria, ed. by M. Landolfi (Rome, 2000), 131-7.

15. L. Forti, La ceramica di Gnathia (Naples, 1965); B. Kirigin, Issa, grčki grad na Jadranu (Zagreb, 1996), 132-3; B. Kirigin, J. Hayes and P. Leach, "Local pottery production at Pharos", Greek influence along the east Adriatic coast, ed. by N. Cambi, S. Čače, and B. Kirigin (Split, 2002), 241-60.

16. J. J. Wilkes, The Illyrians (Oxford, 1992), 196-7.

17. J. J. Wilkes, Dalmatia (history of the Roman provinces) (London, 1969), 50.

18. D. Pingree, From astral omens to astrology: From Babylon to Bikaner (Rome, 1997), 21 and 26; Evans, op. cit. (ref. 3), 1, 2 and 34.

19. Wilkes, op. cit. (ref. 17).

20. B. Kirigin, Pharos, the Parian settlement in Dalmatia: A study of a Greek colony in the Adriatic (British Archaeological Reports International Series 1561; Oxford, 2006).

21. Kirigin, op. cit. (ref. 15).

22. Z. Marić, "Die hellenistische Stadt oberhalb Ošanići bei Stolac (Ostherzegowina)", Bericht der Römisch-Germanische Komission, 1xxvi (1995), 30-72.

23. S. Forenbaher and P. Rajić Šikanjić, "The prehistoric hillfort at Grad (Pelješac, Dalmatia): Preliminary 
results of intensive surface survey", Collegium Antropologicum, xxx (2006), 467-73.

24. Forenbaher and Kaiser, op. cit. (ref. 13).

25. Evans, op. cit. (ref. 3), 36.

26. Abry, op. cit. (ref. 4).

27. Evans, op. cit. (ref. 3), 36.

28. Forenbaher and Kaiser, Spila Nakovana (ref. 13), 119-27; and "Spila Nakovana" (ref. 13), 578-9.

29. D. Rendić-Miočević, "Ilirske predstave Silvana na kultnim slikama s područja Delmata", Glasnik Zemaljskog muzeja u Sarajevu (arheologija), n.s., x (1955), 5-40; A. Stipčević, The Illyrians: History and culture (Park Ridge, NJ, 1977), and Kultni simboli kod Ilira (Sarajevo, 1981); B. Gabričević, Studije i članci o religijama i kultovima antičkog svijeta (Split, 1987).

30. Evans, op. cit. (ref. 3), 37. 